\title{
Characterization of Genomic Clones and Expression Analysis of the Three Types of Superoxide Dismutases During Nodule Development in Lotus japonicus
}

\author{
Maria C. Rubio, ${ }^{1,2}$ Manuel Becana, ${ }^{2}$ Shusei Sato, ${ }^{3}$ Euan K. James, ${ }^{4}$ Satoshi Tabata, ${ }^{3}$ and \\ Herman P. Spaink ${ }^{1}$ \\ ${ }^{1}$ Department of Cell Biology, Institute of Biology, Leiden University, Wassenaarseweg 64, 2333 AL Leiden, \\ The Netherlands; ${ }^{2}$ Departamento de Nutrición Vegetal, Estación Experimental de Aula Dei, Consejo Superior de \\ Investigaciones Científicas, Apdo 202, 50080 Zaragoza, Spain; ${ }^{3}$ Kazusa DNA Research Institute 2-6-7 Kazusa-Kamatari, \\ Kisarazu, Chiba 292-0818, Japan; ${ }^{4}$ Centre for High Resolution Imaging and Processing, MSI/WTB Complex, \\ School of Life Sciences, University of Dundee, Dundee DD1 5EH, U.K.
}

Submitted 27 June 2006. Accepted 21 September 2006.

\begin{abstract}
Superoxide dismutases (SODs) are metalloenzymes that play a primary role in the protection against oxidative stress in plants and other organisms. We have characterized four $S O D$ genes in Lotus japonicus and have analyzed their expression in roots and four developmental stages of nodules. The expression of cytosolic CuZnSOD, at the mRNA, protein, and enzyme activity levels, decreases with nodule age, and the protein is localized in the dividing cells and infection threads of emergent nodules and in the infected cells of young nodules. The mitochondrial MnSOD was downregulated, whereas the bacteroidal MnSOD displayed maximal protein and enzyme activity levels in older nodules. Two additional genes, encoding plastidic (FeSOD1) and cytosolic (FeSOD2) FeSOD isoforms, were identified and mapped. The genes are located in different chromosomes and show differential expression. The FeSOD1 mRNA level did not change during nodule development, whereas $\mathrm{FeSOD} 2$ was upregulated. The distinct expression patterns of the $S O D$ genes may reflect different regulatory mechanisms of the enzyme activities during nodule ontogeny. In particular, at the mRNA and activity levels, the virtual loss of cytosolic CuZnSOD in mature and old nodules, concomitant with the induction of FeSOD2, suggests that the two enzymes may functionally compensate each other in the cytosol at the late stages of nodule development.
\end{abstract}

Additional keywords: differential gene expression, model legume.

Legume nodules are symbiotic structures formed by the molecular interaction between soil rhizobia and plant roots. The bacteroids housed in the nodules are capable of fixing atmospheric $\mathrm{N}_{2}$ at the expense, ultimately, of the energy derived from photosynthates translocated from the shoot. Nodules con-

Corresponding author: M. C. Rubio; E-mail: mcr@eead.csic.es

Nucleotide sequence data reported are available in the GenBank database under accession numbers AY257198 for LjCuZnSODc, AY274807 for LjMnSOD, AY525601-AY525602 for LjFeSOD1, and AY525603AY525604 for LjFeSOD2. tain antioxidant enzymes and metabolites to protect $\mathrm{N}_{2}$ fixation from reactive oxygen species, such as the superoxide radicals and $\mathrm{H}_{2} \mathrm{O}_{2}$, which can be formed, among other processes, by the autoxidation of leghemoglobin in the cytosol, the oxidation of nitrogenase and ferredoxin in the bacteroids, and the electron transport chains of the mitochondria, bacteroids, peroxisomes, and endoplasmic reticulum (Dalton 1995; Matamoros et al. 2003). Antioxidant enzymes may fulfill additional functions by regulating the concentration of reactive oxygen species, which act as second messengers in signaling pathways (Mittler et al. 2004).

The superoxide dismutase (SOD; EC 1.15.1.1) family of metalloenzymes catalyze the dismutation of superoxide radicals to $\mathrm{O}_{2}$ and $\mathrm{H}_{2} \mathrm{O}_{2}$ and, thus, represent a primary line of defense against oxidative damage in virtually all organisms (Scandalios 1997). Three types of SODs, containing $\mathrm{Cu}$ and $\mathrm{Zn}, \mathrm{Mn}$, or Fe in the active site, may coexist in plant tissues. All of them were detected in nodules by assaying enzyme activity in crude extracts or purified organelles. These studies showed that the CuZnSODs are in the cytosol and plastids, the MnSODs in the bacteroids and mitochondria, and the FeSODs in the plastids (Becana et al. 1989; Puppo et al. 1987). Recent work using RNA in situ hybridization and immunogold-labeling techniques revealed that the cytosolic CuZnSOD (CuZnSODc) and the mitochondrial MnSOD display different expression patterns (mRNA and protein) in indeterminate nodules, which suggests specific protective roles for the two types of enzymes (Rubio et al. 2004).

The FeSODs are the most enigmatic type of SODs in plants. Previously thought to be present only in a few families of higher plants (Bridges and Salin 1981), it is now generally believed that the $F e S O D$ genes are widespread, albeit not always expressed, in the plant kingdom (Van Camp et al. 1990). Plant FeSODs typically are localized in the chloroplasts (Tsang et al. 1991; Van Camp et al. 1990); however, recently, an FeSOD isoform has been localized in the cytosol of Vigna unguiculata nodules (Moran et al. 2003). Thus, at least two FeSOD isoforms, differing in subcellular localization, may occur in legumes (Moran et al. 2003; Rubio et al. 2001). Little is known about the structure and function of the FeSOD genes. Three FeSOD genes have been identified in Arabidopsis thaliana (Kliebenstein et al. 1998) and two in Oryza sativa (Kaminaka et al. 1999 and 
GenBank accession number XM_550506), which were reported to encode plastidic proteins.

In this work, we have characterized $S O D$ genes of the model legume Lotus japonicus and its symbiotic partner, Mesorhizobium loti. In addition to the genes encoding cytosolic CuZnSOD ( $L j C u Z n S O D c)$ and mitochondrial MnSOD (LjMnSOD), we have identified and mapped two genes (LjFeSODI and LjFeSOD2) encoding plastidic and cytosolic FeSOD isoforms, respectively. Gene expression and immunohistochemical studies show downregulation of $L j C u Z n S O D c$ and $L j M n S O D$, no effect on $\mathrm{LjFeSOD1}$ expression, and upregulation of $\mathrm{LjFeSOD2}$ during nodule development. The mRNA level of the bacteroidal MnSOD gene (MlMnSOD) was maximal in young nodules and then decreased slightly, whereas the corresponding protein and enzyme activity were highest in older nodules. Results reveal a switch in the expression of LjCuZnSODc (predominant in young nodules) and LjFeSOD2 (predominant in old nodules) in the cytosol of host cells, suggesting different regulatory mechanisms and functions for the two enzymes during nodule ontogeny.

\section{RESULTS}

\section{Identification and characterization of $L j S O D$ genes.}

The first aim of this study was to identify $S O D$ genes of $L$. japonicus. A search in the TIGR Lotus Gene Index database allowed us to obtain the complete open reading frames (ORFs) of $\mathrm{LjCuZnSODc}$ (TC8588) and LjMnSOD (TC8244). However, because there was a single expressed sequence tag (EST) encoding a putative FeSOD (BP034738), an L. japonicus nodule cDNA library was polymerase chain reaction (PCR) screened using degenerated (based on higher plant FeSOD cDNAs) or specific (based on the EST) primers. As a result, we isolated cDNA clones corresponding to two genes, designated as LjFeSOD1 and LjFeSOD2.

The complete genomic sequences were obtained by screening bacterial artificial chromosome $(\mathrm{LjCuZnSODc)}$ ) or transformation-competent artificial chromosome (LjMnSOD, LjFeSOD1, and LjFeSOD2) genomic libraries. The relevant clones and chromosome map positions of the genes are indicated in Table 1. The exon-intron organization of the LjSOD genes was determined by BLAST2 alignment of the cDNA and genomic sequences (Fig. 1). The $\mathrm{LjCuZnSODc}$ gene contains eight exons and the first intron is inserted within the $5^{\prime}$-untranslated region (UTR), as occurs with the CuZnSODc genes of Zea mays (Sod4 and Sod4A), A. thaliana (At1g08830; CSD1), and other higher plants (Scandalios 1997). The placement of the intron in the $5^{\prime}$ UTR is similar, at 12, 20, and $13 \mathrm{bp}$ upstream of the start site of translation for the genes of Z. mays, A. thaliana, and L. japonicus, respectively. The LjMnSOD gene consists of six exons, of which exons two to five have identical or similar sizes to those of the homologous genes of $A$. thaliana (At3g10920; MSD1), O. sativa (AB026725), and Pisum sativum (U30841). The LjCuZn-
SODc and $L j M n S O D$ nucleotide sequences at the exon-intron boundaries conform to the GT-AG rule for splice junction sites of eukaryotic genes (Shapiro and Senapathy 1987). The two LjFeSOD genes consist of nine exons with identical or similar sizes, whereas the three $F e S O D$ genes of $A$. thaliana contain seven (At4g25100; FSD1), nine (At5g51100; FSD2), or eight (At5g23310; FSD3) exons (Kliebenstein et al. 1998). Interestingly, the exon-intron boundaries of the three genes of $A$. thaliana follow the GT-AG consensus sequence for splice junctions, whereas the exon four-intron four boundaries of the two LjFeSOD genes have, instead, a GC-AG splice site. These GCAG introns are the most abundant subtype of noncanonical introns, comprising 1.1 and $2.5 \%$ of cDNA-supported introns in A. thaliana and O. sativa, respectively (Sparks and Brendel 2005). Although no significant over-representation in any particular functional class for GC-AG intron-containing genes was observed, a subset of GC-AG introns is reported to be involved in alternative splicing or in splicing regulation (Farrer et al. 2002).

The predicted properties of the LjSOD proteins are indicated in Table 1. The MitoProtII, PSORT, ChloroP, and TransitP prediction programs confirmed that LjMnSOD and LjFeSOD1 have N-terminal transit peptides for sorting to the mitochondria and chloroplasts, respectively, and that $\mathrm{LjCuZnSODc}$ and LjFeSOD2 lack any signal for organelle targeting and are localized in the cytosol. The LjFeSOD proteins displayed poor homology (57\% of identity) between them. There also was low homology between the LjFeSODs and the A. thaliana FeSODs. The highest sequence identities $(60 \%)$ were found between LjFeSOD1 and FSD2 or between LjFeSOD2 and FSD1. The two LjFeSODs and the three A. thaliana FeSODs contain the sod-Fe-N ( $\alpha$-hairpin) domain and the sod-Fe-C $(\alpha / \beta$-carboxyl terminal) domain, which are typical of plant FeSODs (Fink and Scandalios 2002). The complete FeSOD amino acid sequences from plants available in the databases were used to construct a phylogenetic tree with five groups (Fig. 2A). Cluster I includes the FeSODs from monocots, Gossypium hirsutum, and $A$. thaliana (FSD3); clusters II and III, most of the FeSODs from dicots; cluster IV, the FeSODs from green algae; and cluster V, the FeSODs from mosses, ferns, and gymnosperms. The FeSOD from Zantedeschia aethiopica was not rooted in any of the clusters. The prediction programs indicated that the FeSODs in the various clusters differ in their subcellular localization, with a few exceptions (Fig. 2A). Clusters I and II contain FeSODs with a chloroplast signal peptide, except for the enzyme of $G$. hirsutum, which is devoid of it. Conversely, cluster III contains FeSODs without transit peptide, suggesting a cytosolic localization, except for the enzyme of Lycopersicon esculentum, which is predicted to have a chloroplast transit peptide. It is worth noting that A. thaliana FSD1, annotated as a putative plastidic isoform (Kliebenstein et al. 1998), groups in this cluster. However, in silico sequence analyses of the three $A$. thaliana FeSODs confirm the prediction that FSD2 and FSD3 are plastidic isoforms

Table 1. Characteristics of $L j S O D$ genes and predicted properties of the derived proteins

\begin{tabular}{|c|c|c|c|c|c|c|c|c|c|}
\hline Gene & $\begin{array}{l}\text { Genomic } \\
\text { clone }\end{array}$ & $\begin{array}{c}\text { Accession } \\
\text { number }\end{array}$ & Chromosome & $\underset{\text { position }^{a}}{\text { Map }}$ & ORF $^{\mathbf{b}}$ & Protein $^{c}$ & $\mathbf{M}^{\mathbf{d}}$ & $\mathbf{p I}^{\mathrm{e}}$ & $\begin{array}{l}\text { Subcellular } \\
\text { localization }^{f}\end{array}$ \\
\hline $\mathrm{LjCuZnSODc}$ & LjB12K22 & AY257198 & $\ldots$ & $\ldots$ & 459 & 152 & 15.1 & 5.64 & Cytosol \\
\hline LjMnSOD & LjT13P21 & AY274807 & 1 & 1.2 & 741 & 246 & 26.9 & 7.20 & Mitochondria \\
\hline LjFeSOD1 & LjT32I13 & AY525602 & 6 & 2.1 & 936 & 311 & 35.5 & 5.83 & Plastids \\
\hline LjFeSOD2 & LjT45M19 & AY525604 & 5 & 23.5 & 753 & 250 & 28.0 & 5.66 & Cytosol \\
\hline
\end{tabular}

\footnotetext{
${ }^{a}$ Map position of the genes on the chromosomes in centimorgans.

${ }^{\mathrm{b}}$ Open reading frame (ORF) in base pairs.

${ }^{\mathrm{c}}$ Number of amino acid residues of protein precursors.

${ }^{\mathrm{d}}$ Theoretical molecular mass $(\mathrm{M})$ of the protein precursors in kilodaltons.

${ }^{\mathrm{e}}$ Calculated isoelectric point (pI) of the proteins.

${ }^{\mathrm{f}}$ Predicted subcellular localizations by ChloroP, MitoProt, TargetP, and PSORT programs.
} 
(Kliebenstein et al. 1998), but suggest that FSD1 is a cytosolic protein, in agreement with phylogenetic groupings. Finally, cluster IV includes FeSODs with putative mitochondrial transit peptides and cluster $\mathrm{V}$ contains proteins with ambiguous subcellular localization, except for the enzyme of the moss Barbula unguiculata, which lacks any transit peptide (Fig. 2A). The LjFeSOD1 and LjFeSOD2 proteins are grouped in separate clusters, which is consistent with their putative localizations in the chloroplasts and cytosol, respectively (Fig. 2A). The alignment of the $\mathrm{N}$-terminal sequences of legume FeSODs gives strong support for the existence of two distinct types of isoforms according to the presence or absence of transit peptides for organelle targeting (Fig 2B). Of particular interest is that, of the three FeSODs reported in Glycine max, isoforms 1 and 2 are predicted to be located to the cytosol (clustering with LjFeSOD2) and only isoform 3 to the plastids (Fig. 2A and B).

\section{Expression of $L j S O D$ genes and proteins during nodule development.}

The steady-state mRNA levels of the LjSOD genes were determined by quantitative reverse-transcription (qRT)-PCR in young roots $(\mathrm{R})$ and in emergent $(\mathrm{N} 1)$, young $(\mathrm{N} 2)$, mature (N3), and old (N4) nodules. To monitor nodule development, several markers were quantified simultaneously to the mRNA levels of the $L j S O D$ genes (Fig. 3). These include the mRNA levels of the cytosolic ascorbate peroxidase $(L j A P X C)$ and "nodule inception" (LjNin) genes of L. japonicus and of the nifH gene of $M$. loti (MlnifH). The APXc of nodules accounts for up to $0.9 \%$ of the soluble protein and its activity is correlated with $\mathrm{N}_{2}$ fixation (Dalton et al. 1987). The NIN protein is involved in nodule inception and development (Schauser et al. 1999). As expected, the mRNAs of LjAPXc and LjNin were particularly abundant in emergent or young nodules, and declined in old nodules. The expression of the MlnifH gene, a useful marker of bacteroid activity, increased by approximately 400-fold in young nodules and moderately declined in mature and old nodules, but remained above the value of emergent nodules (Fig. 3). The MlMnSOD of bacteroids showed maximum expression at the mRNA level in young, mature, and old nodules. The $L j S O D$ genes were differentially expressed during nodule development. The mRNA levels of $\mathrm{LjCuZn-}$
$S O D c$ in roots and emergent nodules were similar, and decreased in young, mature, and old nodules (Fig. 3). A similar response was observed for the mRNA levels of $L j M n S O D$. In sharp contrast, the expression of $L j F e S O D 1$ remained constant and LjFeSOD2 mRNA levels increased by 20-, 124-, and 79fold in young, mature, and old nodules, respectively (Fig. 3).

The relative abundance of LjSOD proteins at the different developmental stages of nodules was determined by immunoblots after sodium dodecyl sulfate polyacrylamide gel electrophoresis (SDS-PAGE) (Fig. 4A) and native-PAGE (Fig. 4C). Because the polyclonal antibody raised against the MnSOD of $O$. sativa recognized both mitochondrial and bacterial MnSODs, additional immunoblots of native-PAGE gels were performed to differentiate between the two nodule enzymes. Extracts of free-living $M$. loti bacteria and partially purified $M$. loti bacteroids, roots, and leaves were included in the blots to verify enzyme identities (Fig. 4B). The MnSOD antibody recognized two protein bands in nodules and a single protein band in the other extracts. The upper immunoreactive band of nodule extracts was assigned to mitochondrial LjMnSOD and the lower immunoreactive band to bacterial MIMnSOD by comparison with the bands observed in the bacteria, bacteroid, root, and leaf extracts (Fig. 4B). However, the LjFeSOD1 and LjFeSOD2 isoforms could not be differentiated in the immunoblots and the proteins were quantified together. The LjFeSOD proteins were absent in emergent and young nodules, but were abundant in mature and old nodules (Fig. 4A). In sharp contrast, the $\mathrm{LjCuZnSODc}$ protein was virtually undetectable in the mature and old nodules (Fig. 4A). The LjMnSOD protein declined in young relative to emergent nodules, and remained low in the older nodules, whereas the MIMnSOD protein could not be detected in emergent nodules and increased with nodule age (Fig. 4C).

The isoform composition of LjSODs in nodules was determined by native-PAGE and differential inhibition with cyanide or $\mathrm{H}_{2} \mathrm{O}_{2}$ prior to activity staining of gels. The nodule extracts contained two CuZnSOD isoforms (cytosol and plastids), two MnSOD isoforms (mitochondria and bacteroids), and two FeSOD isoforms (cytosol and plastids). The total SOD activity was approximately 21 units per milligram of protein for all developmental stages, but isoform pattern was markedly affected
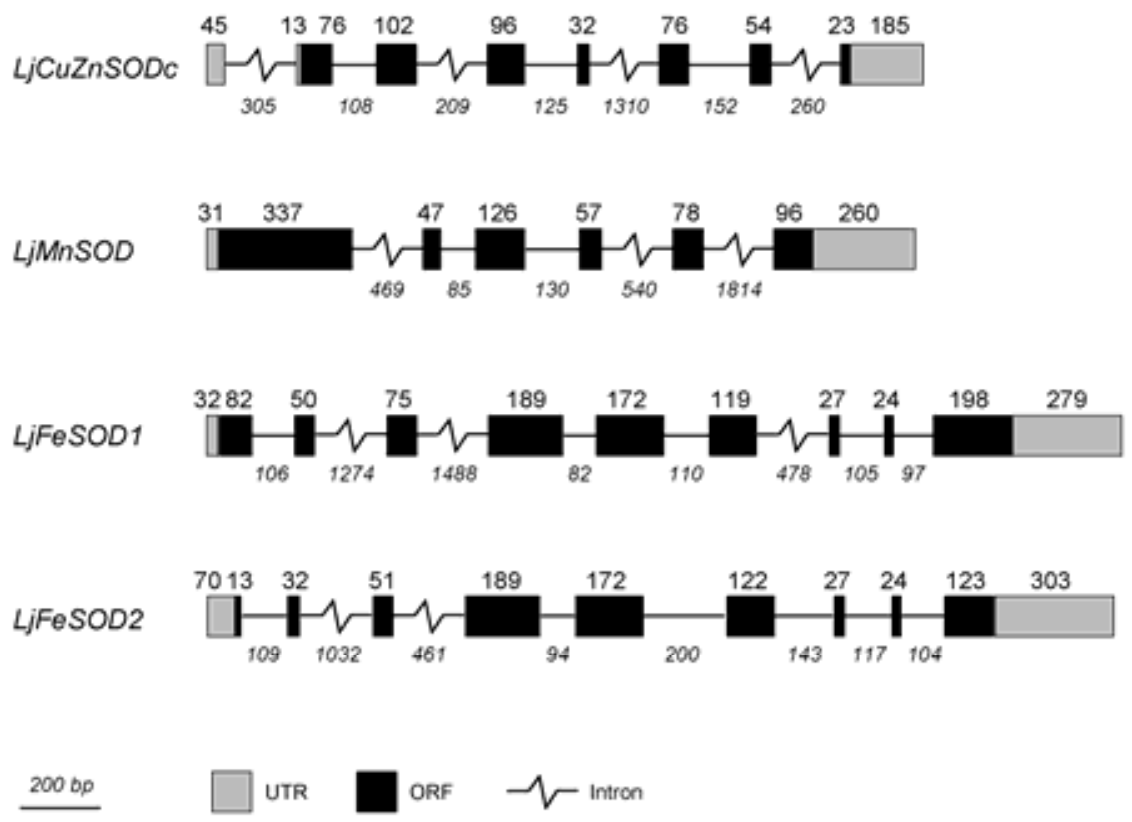

Fig. 1. Exon-intron organization of $L j S O D$ genes. The untranslated regions (UTRs) are depicted in gray boxes, the open reading frames (ORFs) in black boxes, and introns in straight lines. Disrupted lines denote intron lengths not drawn to scale. All other lengths are drawn to scale and the bar is 200 bp. 


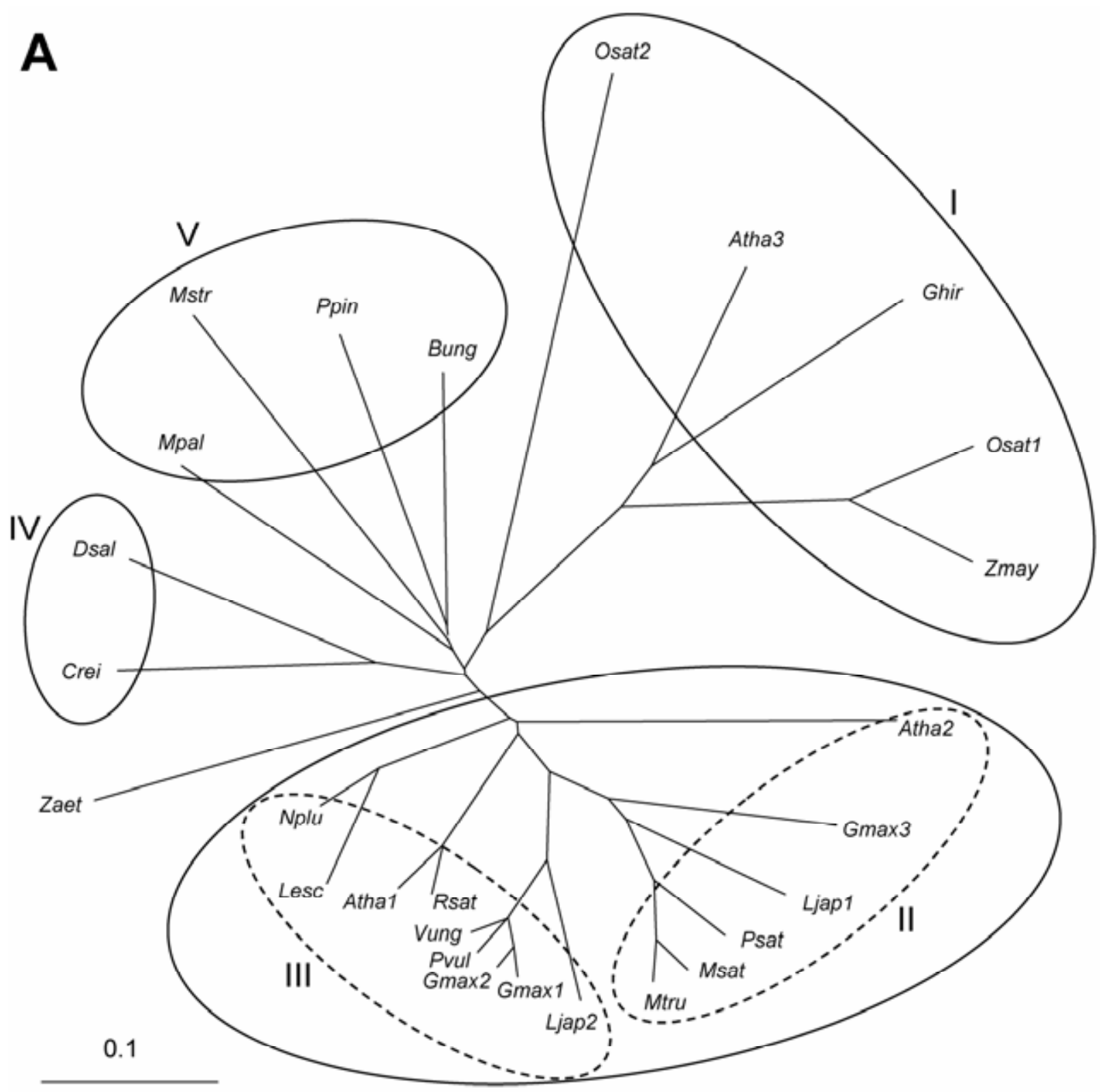

B

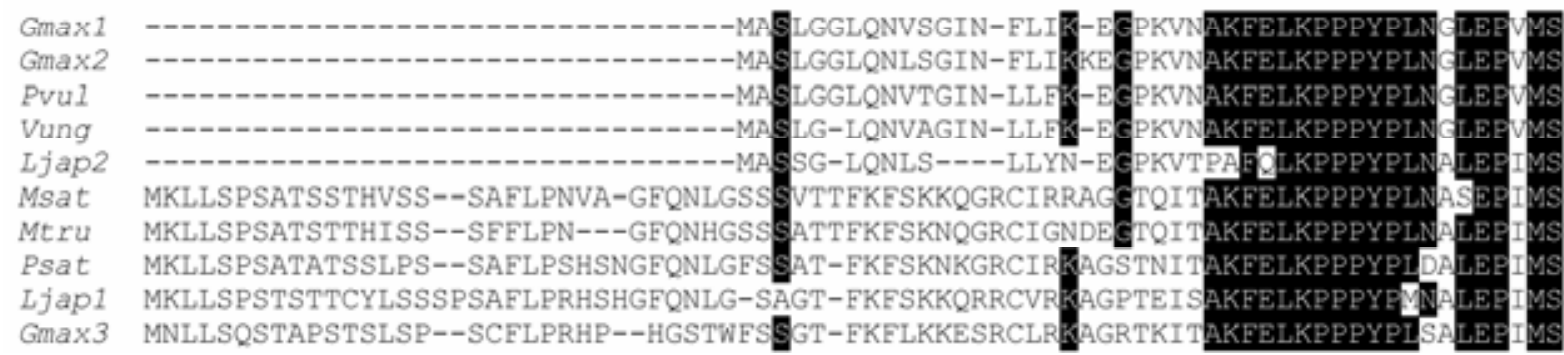

Fig. 2. A, Unrooted phylogenetic tree of FeSOD proteins from plants. The tree was constructed by using the neighbor-joining method of CLUSTALW, with 1,000 bootstraps. The bar indicates 0.1 substitution per site. GenBank accession numbers are: Atha1 (Arabidopsis thaliana FSD1, P21276), Atha2 (A. thaliana FSD2, NP_199923), Atha3 (A. thaliana FSD3, NP_197722), Bung (Barbula unguiculata, BAC66946), Crei (Chlamydomonas reinhardtii, AAB04944), Dsal (Dunaliella salina, AAX92665), Ghir (Gossypium hirsutum, ABA00456), Gmaxl (Glycine max isoform 1, P28759), Gmax2 (G. max isoform 2, AAQ13492), Gmax3 (G. max isoform 3, TC218521), Lesc (Lycopersicon esculentum, AAQ18699), Ljap1 (Lotus japonicus FeSOD1, AAS92465), Ljap2 (L. japonicus FeSOD2, AAS92467), Mpal (Marchantia paleacea, BAC66948), Msat (Medicago sativa, AAL3244), Mstr (Matteuccia struthiopteris, BAD13298), Mtru (Medicago truncatula, TC101551), Nplu (Nicotiana plumbaginifolia, A39267), Osat1 (Oryza sativa isoform 1, XP_550626), Osat2 (O. sativa isoform 2, XP_550506), Ppin (Pinus pinaster, AAS47494), Psat (Pisum sativum partial FeSOD, CAD42655), Pvul (Phaseolus vulgaris, TC2739), Rsat (Raphanus sativus, AAC15842), Vung (Vigna unguiculata, AAF28773), Zaet (Zantedeschia aethiopica, AAC63378), and Zmay (Zea mays, BAD89495). B, Alignment of the deduced N-terminal sequences of legume FeSODs. White letters on a black background represent conserved residues on seven or more sequences. 
by nodule age. As compared with the LjCuZnSODc, the activity of plastidic $\mathrm{LjCuZnSOD}$ was minor and the protein was not recognized by the CuZnSODc antibody (data not shown). The specific activity of $\mathrm{LjCuZnSODc}$ was approximately 7 units per milligram of protein at the early stages of symbiosis but became undetectable in mature and old nodules, whereas the LjMnSOD activity was 13 units per milligram of protein in emergent nodules, decreased by $46 \%$ in young nodules, and remained at that low level thereafter (Fig. 5). The MlMnSOD activity was undetectable in emergent nodules but increased in mature and old nodules relative to young nodules. The total FeSOD activity (LjFeSOD1 and LjFeSOD2) was detectable only in mature and old nodules, with values of 4 to 5 units per milligram of protein (Fig. 5).

Immunohistolocalization of SODs in nodules.

The SOD proteins were immunolocalized in L. japonicus nodules at the four developmental stages using confocal laser-

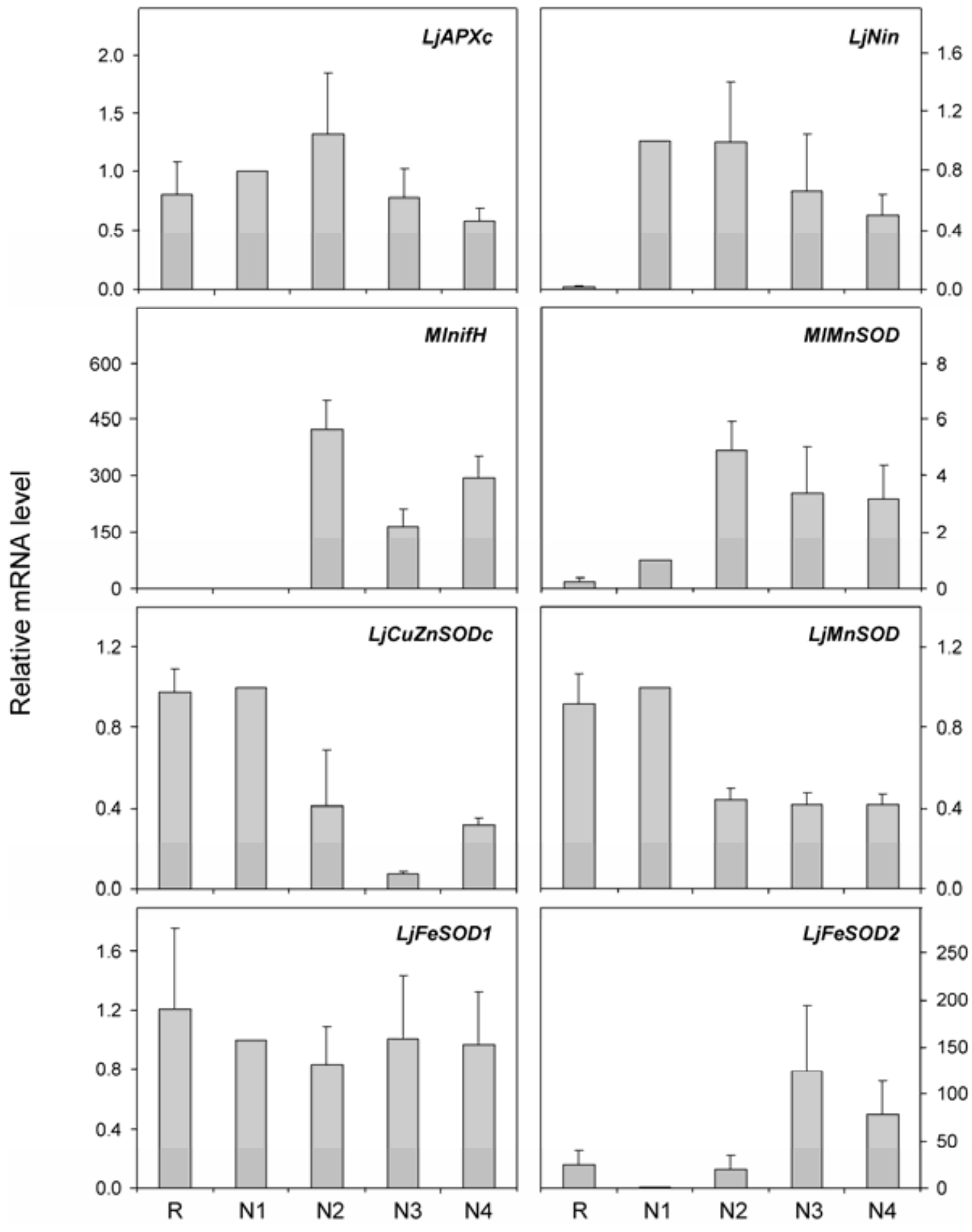

Fig. 3. Expression of $L j S O D$ genes during nodule development. Steady-state mRNA levels were quantified by quantitative reverse-transcription polymerase chain reaction in roots $(\mathrm{R})$ and in emergent $(\mathrm{N} 1)$, young $(\mathrm{N} 2)$, mature $(\mathrm{N} 3)$, and old $(\mathrm{N} 4)$ nodules. The mRNA levels were normalized with respect to the housekeeping genes and were expressed relative to those of N1 nodules, which were arbitrarily given a value of 1 . Data are means \pm standard error of four biological replicates (RNA preparations) from at least three series of plants grown independently. 
scanning microscopy. In addition, differential interference contrast, combined with fluorescence microscopy, was used for a more precise localization of the proteins in emergent nodules. The LjCuZnSODc protein was localized in the central zone of emergent and young nodules (Fig. 6A and B), whereas the signal was barely detected in mature and old nodules (Fig. 6C and D). At the cellular level, LjCuZnSODc was localized in the cytoplasmic bridges of dividing cells (Fig. 6E) and in the infection threads (Fig. 6F) of emergent nodules. There was some weak labeling in the cytosol of infected cells in young nodules (Fig. 6G). No fluorescent signal was observed in nodule sections incubated with either the primary antibody (data not shown) or the secondary antibody alone (Fig. 6H).
The LjMnSOD and MlMnSOD proteins were localized with the same polyclonal antibody. The LjMnSOD was detected in the subtending roots of emergent nodules (Fig. 7A) and the MIMnSOD was found predominantly in the central zone of emergent nodules (Fig. 7A) and in the infected cells of young, mature, and old nodules (Fig. 7B through D). The labeling associated with MIMnSOD increased in the infected cells with nodule age (Fig. 7A through D). In fact, because the bacteroids outnumber by far the mitochondria in the infected cells (Bergersen 1982), the high fluorescence signal observed in the central zone is due mainly to MlMnSOD rather than LjMnSOD. This can be confirmed by the observation, at higher magnifications, that the signal was visible in the bacteria within infection threads of emergent nodules (Fig. 7E and

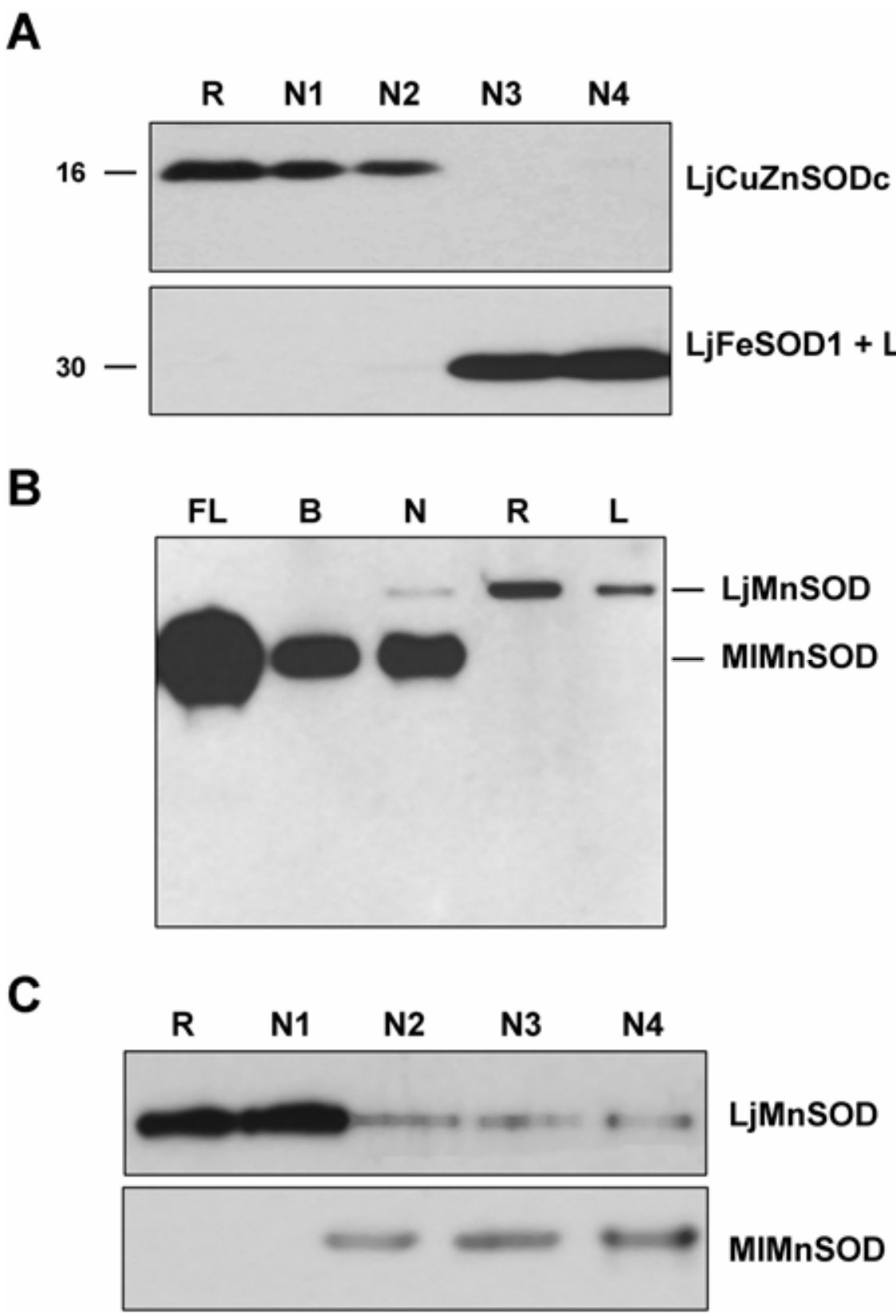

Fig. 4. Immunoblot analysis of LjSOD proteins during nodule development. A, Sodium dodecyl sulfate polyacrylamide gel electrophoresis (SDS-PAGE) of soluble extracts from roots (R) and from emergent (N1), young (N2), mature (N3), and old (N4) nodules. Approximate molecular masses (kDa) are indicated on the left. Lanes contained $30 \mu \mathrm{g}$ (LjCuZnSODc) or $25 \mu \mathrm{g}$ (LjFeSOD) of protein. B, Native-PAGE of soluble extracts from free-living bacteria (FL), bacteroids (B), nodules (N), roots (R), and leaves (L). Lanes contained $25 \mu \mathrm{g}$ (FL, N, R, and L) or $13 \mu \mathrm{g}$ (B) of protein. C, Native-PAGE of soluble extracts from roots and nodules of the same developmental stages as for panel A. To avoid signal saturation, different exposure times were used to visualize the LjMnSOD and MIMnSOD protein bands. Lanes contained $25 \mu \mathrm{g}$ of protein. 
F) and in the bacteroids of infected cells in the other developmental stages (Fig 7G). In the oldest nodules, dense labeling also was found in decaying infected cells (Fig. 7H). Control sections did not show any signal (data not shown).

The LjFeSOD protein was localized in the cortex and central zone of emergent nodules and in the subtending roots (Fig. 8A), and in the cortex, vascular bundles, and infected zone of emergent (Fig. 8B), mature (Fig. 8C), and old (Fig. 8D) nodules. At the cellular level, the LjFeSOD protein was found predominantly in the amyloplasts at all stages of nodule development (Fig. 8E through G). There was also some weak labeling in the cytosol of mature nodules, particularly in "patches" next to the cell walls (Fig. 8G). The signal was slightly enhanced with nodule age. Control sections did not show any signal (Fig. 8H).

\section{Immunogold localization of $\mathrm{LjFeSODs}$ in nodules.}

Immunogold electron microscopy was used to verify the subcellular localization of the two FeSOD proteins in mature nodules (N3) of L. japonicus. Ultrathin sections were incubated with the same FeSOD antibody used for fluorescence and confocal microscopy studies and with a gold-conjugated goat anti-rabbit antibody. Consistent labeling was observed in the cytosol and amyloplasts of uninfected (Fig. 9A and B) and infected (Fig. 9C) cells, which evidences the presence of the LjFeSOD1 (plastid) and LjFeSOD2 (cytosol) isoforms in nodules. No labeling was observed in sections incubated with nonimmune serum (Fig. 9D).

\section{DISCUSSION}

The SODs are abundant antioxidants in plants, where they have the additional burden of scavenging the reactive oxygen species produced in photosynthesis. However, little is known about the expression of SODs in nonphotosynthetic tissues. In this work, we have characterized the genomic sequences of four
SOD genes of the model legume L. japonicus and compared their expression at various stages of nodulation. These comparisons provide support for diverse functions of the SOD isoforms during symbiosis.

The LjCuZnSODc and LjMnSOD genes show exon-intron structures similar to the homologous genes of $Z$. mays (Scandalios 1997) and A. thaliana (Kliebenstein et al. 1998). Interestingly, the 5'-UTR of the $\mathrm{LjCuZnSODc}$ gene is interrupted by the first intron. This also was the case with other plant $C u Z n S O D c$ genes (Kliebenstein et al. 1998; Scandalios 1997) as well as for the $A P X c$ gene of P. sativum (Mittler and Zilinskas 1992). The first intron interrupting the $5^{\prime}$-UTR of higher plant $C u Z n S O D c$ genes revealed strong structural conservation and may have regulatory functions (Scandalios 1997). On the other hand, the two LjFeSOD genes share similar exonintron composition but are located in different chromosomes and code for proteins targeted to different cellular compartments. Phylogenetic analysis, N-terminal sequences, and prediction programs of subcellular localization are consistent with at least two types of FeSODs, localized in the plastids and cytosol, in legumes and other higher plants. The coexistence of the two isoforms is evident in L. japonicus and G. max and, probably, also in $V$. unguiculata and A. thaliana. Additional isoforms may occur in mitochondria (Droillard and Paulin 1990; Srivalli and Khanna-Chopra 2001), although this has not yet been conclusively proven.

The molecular information gathered for the four $L j S O D$ genes was used to examine the expression patterns during nodule development. To our knowledge, this is the first time that the SOD isoforms were localized by immunohistochemistry in a determinate nodule, which is of interest for a comparison with our previous results in indeterminate nodules (Rubio et al. 2004). The steady-state mRNA level of $L j C u Z n S O D c$ markedly decreased with nodule age and the corresponding protein and enzyme activity became virtually undetectable in mature and old nodules.
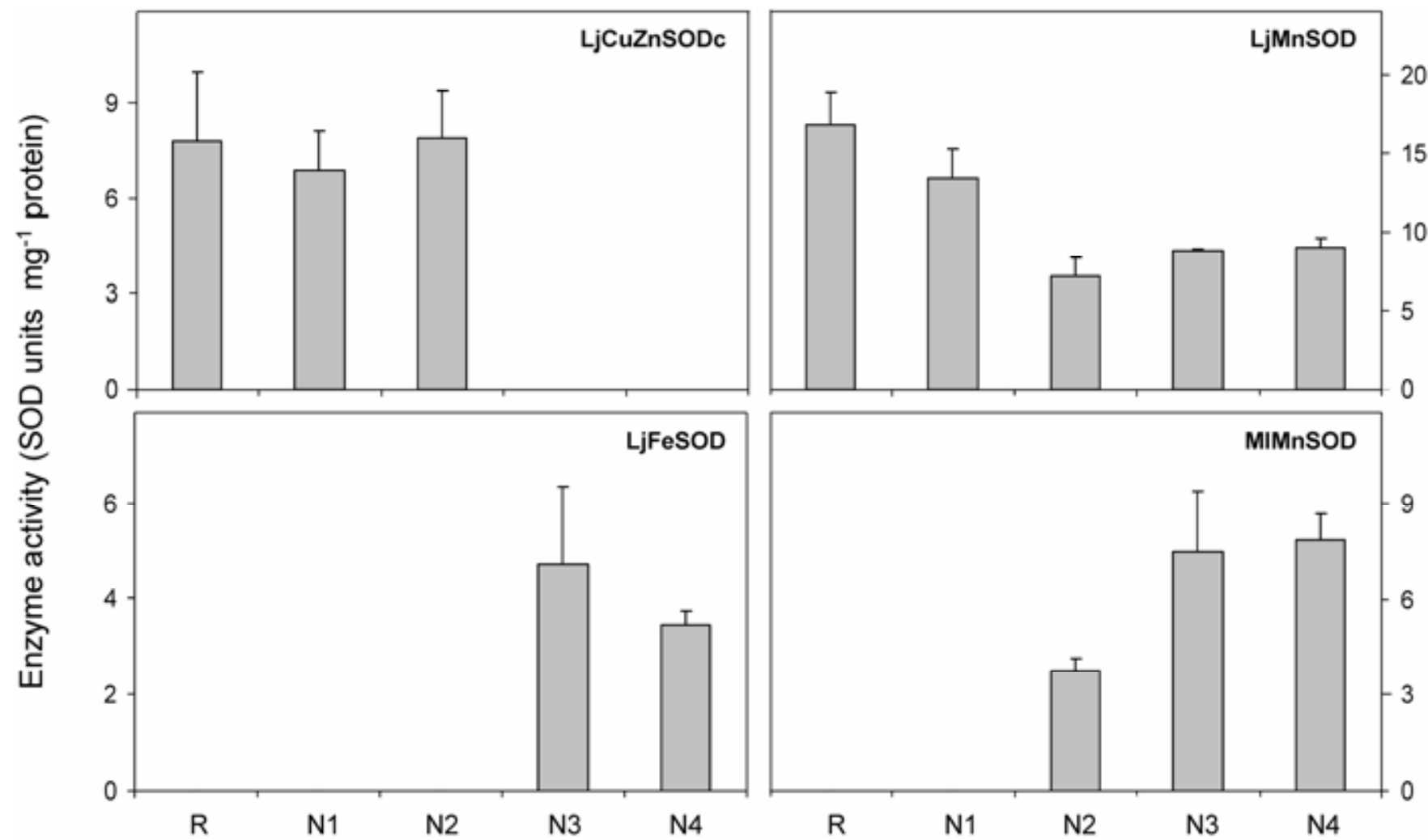

Fig. 5. Specific activities of LjSOD isoforms in roots (R) and in emergent (N1), young (N2), mature (N3), and old (N4) nodules. Data are means \pm standard error of three replicates from at least two series of plants grown independently. 
This indicates that the $L j C u Z n S O D c$ gene is developmentally regulated at the transcriptional level. The high levels of mRNA, protein, and activity in emergent nodules, along with the localization of $\mathrm{LjCuZnSODc}$ in the infection threads, suggest that this enzyme plays an important role early in the symbiosis. As proposed for indeterminate nodules (Rubio et al. 2004), a likely function of $\mathrm{LjCuZnSODc}$ during formation of determinate nodules would be to provide $\mathrm{H}_{2} \mathrm{O}_{2}$ for the crosslinking of the matrix glycoprotein of infection threads. Indeed, accumulation of $\mathrm{H}_{2} \mathrm{O}_{2}$ surrounding infection threads has been observed both in indeterminate nodules of Medicago sativa and $P$. sativum (Rubio et al. 2004; Santos et al. 2001) and in determinate young nodules of $V$. unguiculata (E. K. James, unpublished results). The immunohis- tochemical localization of $\mathrm{CuZnSODc}$ in emergent and young nodules of L. japonicus also is consistent with our previous finding that the CuZnSODc mRNA and activity are more abundant in the younger tissue (meristem and invasion zones) of indeterminate nodules (Rubio et al. 2004). These results, together with the observations that the $\mathrm{CuZnSODc}$ protein content and activity are higher in young than in old leaves of Nicotiana tabacum (Kurepa et al. 1997a), reveal that CuZnSODc expression is associated mainly with young plant tissues, probably engaged in high mitotic and metabolic activity, and that the enzyme is downregulated with advancing age of plant organs.

Two MnSOD enzymes could be distinguished in L. japonicus nodules. As occurs with the homologous enzymes of other leg-
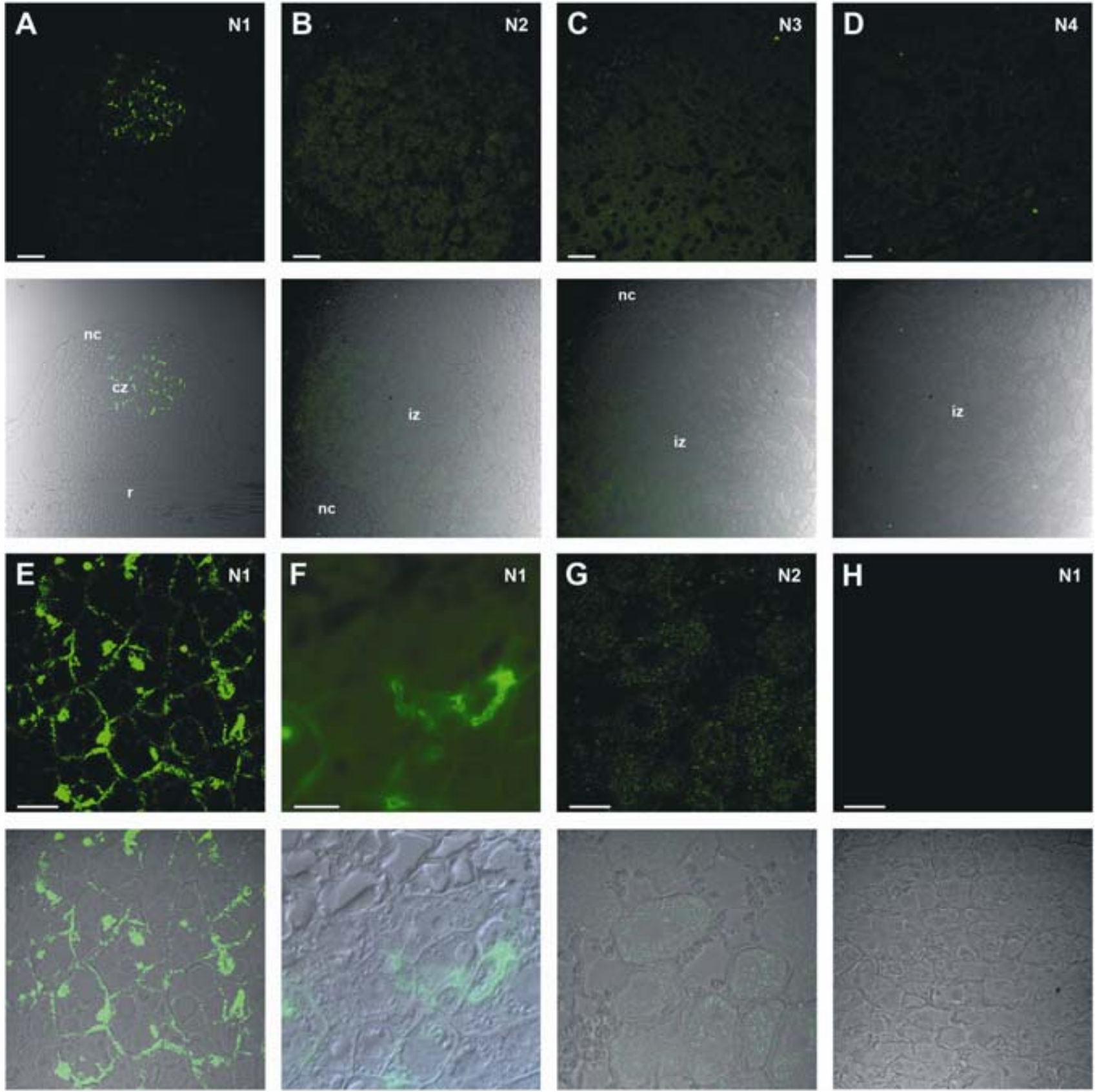

Fig. 6. Immunohistolocalization of LjCuZnSODc in nodules. Images represent longitudinal sections of emergent (N1), young (N2), mature (N3), and old (N4) nodules. A through $\mathbf{D}$, Confocal images $(\times 20)$ representative of all nodule developmental stages. $\mathbf{E}$ and $\mathbf{G}$, Confocal images $(\times 100)$ showing details of similar sections of emergent and young nodules, respectively. F, Image $(\times 100)$ of emergent nodules taken with a fluorescence microscope equipped with differential interference contrast optics. A through $\mathbf{H}$, Upper images show the fluorescent signal and lower images show the merged images with the transmitted light, which allows for signal localization in the tissue. $\mathbf{H}$, Confocal image of a control section incubated only with the secondary antibody. Abbreviations: cz, central zone; iz, infected zone; nc, nodule cortex; r, root. Bars $=50 \mu \mathrm{m}$ (A through D), $15 \mu \mathrm{m}(\mathrm{E}, \mathrm{G}$, and $\mathrm{H})$, and $10 \mu \mathrm{m}(\mathrm{F})$. 
umes (Matamoros et al. 2003), the LjMnSOD of mitochondria is tetrameric and the MlMnSOD of bacteroids is dimeric, but both have similar subunit size (data not shown). Therefore, immunoblots of native-PAGE gels were used to separate the two proteins. The decrease in mRNA, protein, and activity of LjMnSOD reflects that the gene is transcriptionally downregulated during nodule development. However, the regulatory mechanisms of MnSOD expression may vary with the plant species, plant tissue, and stress conditions. Thus, during leaf senescence induced by prolonged darkness, the MnSOD protein and activity levels were upregulated in $P$. sativum (del Rio et al. 2003) but remained unaffected in A. thaliana (Kliebenstein et al. 1998).
A novel contribution of this work is the characterization of two $L j F e S O D$ genes differing in subcellular localization and expression pattern during nodule development. Whereas the mRNA level of plastidic LjFeSOD1 was not affected, cytosolic LjFeSOD2 was upregulated in old nodules. In N. tabacum, the FeSOD mRNA level decreased but the enzyme activity increased with leaf age (Kurepa et al. 1997b). This lack of correlation was not observed for nodule LjFeSOD. Although we were unable to separate the activities of the two LjFeSOD isoforms on either native or isoelectric focusing gels, the increase in the total LjFeSOD protein and activity with nodule age is most likely due to the increase in the LjFeSOD2 mRNA level. The finding that the LjFeSOD1 mRNA level remains constant
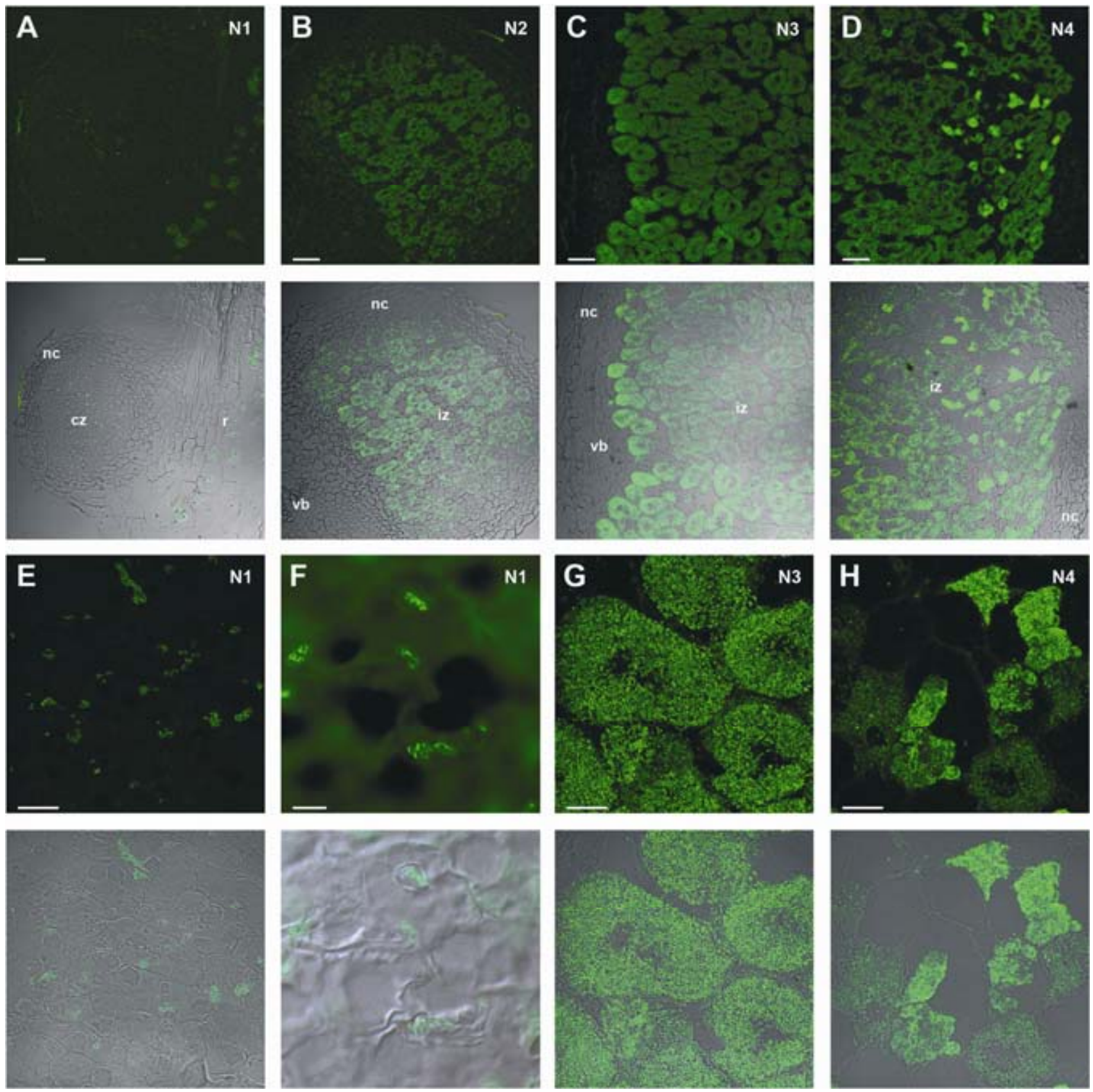

Fig. 7. Immunohistolocalization of MnSOD in nodules. Images represent longitudinal sections of emergent (N1), young (N2), mature (N3), and old (N4) nodules. A through D, Confocal images $(\times 20)$ representative of all nodule developmental stages. E, G, and $\mathbf{H}$, Confocal images $(\times 100)$ showing details of similar sections of emergent, mature, and old nodules, respectively. F, Image $(\times 100)$ of emergent nodules taken with a fluorescence microscope equipped with differential interference contrast optics. A through $\mathbf{H}$, Upper images show the fluorescent signal and lower images show the merged images with the transmitted light, which allows for signal localization in the tissue. Abbreviations: cz, central zone; iz, infected zone; nc, nodule cortex; r, root; vb, vascular bundle. Bars $=50 \mu \mathrm{m}($ A through D), $15 \mu \mathrm{m}(\mathrm{E}, \mathrm{G}$, and $\mathrm{H})$, and $5 \mu \mathrm{m}(\mathrm{F})$. 
also is important because plastidic FeSODs generally are responsive to environmental cues (Kurepa et al. 1997c; Tsang et al. 1991). The existence of a constitutive LjFeSOD1 isoform in nodules could buffer plastids against a sudden triggering of oxidative stress in plants exposed to adverse conditions. In fact, the plastids and amyloplasts appear to be the last organelles being degraded during stress-induced nodule senescence, probably because they contain key antioxidant proteins, such as ferritin, $\gamma$-glutamylcysteine synthetase, and ascorbate peroxidase (Hernández-Jiménez et al. 2002).

More recently, high levels of a cytosolic FeSOD isoform, homolog to LjFeSOD2, were found in mature and old nodules of V. unguiculata (Moran et al. 2003). Intracellular iron may regu- late FeSOD expression in N. tabacum (Kurepa et al. 1997a) and iron capable of catalyzing free radical production has been detected in senescing nodules of Phaseolus vulgaris (Becana and Klucas 1992), G. max (Evans et al. 1999), and Lupinus albus (Hernández-Jiménez et al. 2002). Thus, the enhanced expression of LjFeSOD2 in L. japonicus nodules could be a response, at least in part, to the increase of free iron, perhaps as a result of leghemoglobin degradation in senescing tissue (Moran et al. 2003). Furthermore, the LjFeSOD2 and LjCuZnSODc enzymes might functionally compensate each other in the cytosol of nodule host cells, given the contrasting patterns of their mRNA and activity levels during nodule development. Opposite expression patterns of plastidic CuZnSOD and FeSOD
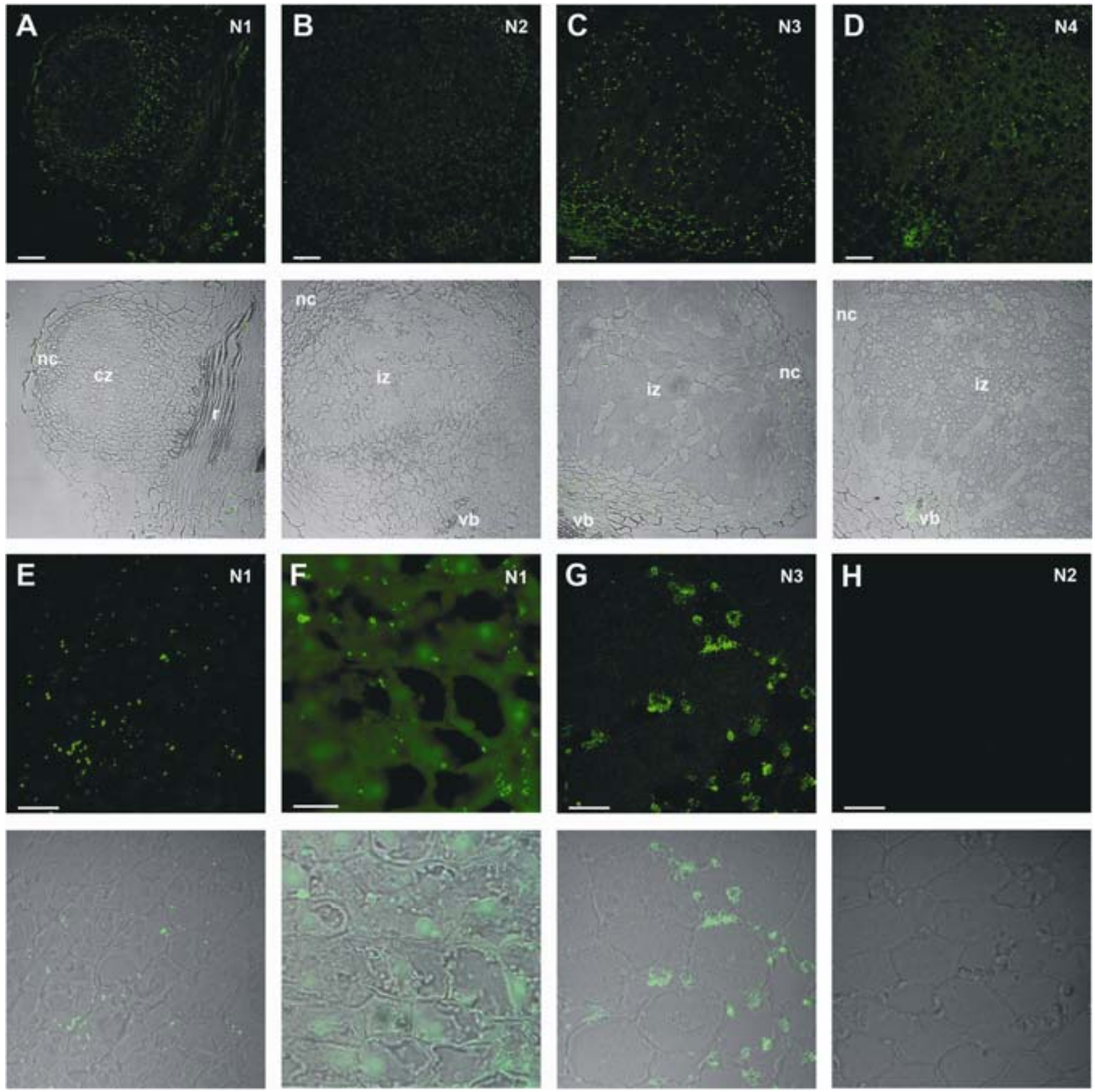

Fig. 8. Immunohistolocalization of LjFeSOD in nodules. Images represent longitudinal sections of emergent (N1), young (N2), mature (N3), and old (N4) nodules. A through D, Confocal images $(\times 20)$ representative of all nodule developmental stages. $\mathbf{E}$ and $\mathbf{G}$, Confocal images $(\times 100)$ showing details of similar sections of emergent and mature nodules, respectively. F, Image $(\times 100)$ of emergent nodules taken with a fluorescence microscope equipped with differential interference contrast optics. A through $\mathbf{H}$, Upper images show the fluorescent signal and lower images show the merged images with the transmitted light, which allows for signal localization in the tissue. H, Confocal image of a control section incubated only with the secondary antibody. Abbreviations: cz, central zone; iz, infected zone; nc, nodule cortex; r, root; vb, vascular bundle. Bars $=50 \mu \mathrm{m}$ (A through D), $15 \mu \mathrm{m}(\mathrm{E}, \mathrm{G}$, and $\mathrm{H})$, and $10 \mu \mathrm{m}(\mathrm{F})$. 
in response to the availability of copper and iron has been reported in leaves of $P$. sativum (Barón Ayala and Sandmann 1988) and N. tabacum (Kurepa et al. 1997c), suggesting a similar compensatory phenomenon of SOD isoforms in the chloroplasts. We currently are studying the regulation of the different types of SODs in L. japonicus using promoter fusions to green fluorescent proteins. Such studies could provide new insights on the molecular basis and biological relevance for the distinct regulation patterns of the $S O D$ genes during legume nodule formation and senescence.

\section{MATERIALS AND METHODS}

\section{Biological material.}

L. japonicus cv. Gifu seed were scarified using sandpaper and germinated at $28^{\circ} \mathrm{C}$ in the dark for 2 days. Seedlings were grown in pots containing vermiculite under environment-con- trolled conditions $\left(150 \mu \mathrm{mol} \mathrm{m} \mathrm{m}^{-2} \mathrm{~s}^{-1}, 16\right.$-h photoperiod, temperature regime of 21 and $18^{\circ} \mathrm{C}$, day and night, respectively) and were inoculated after 2 days with $M$. loti R7A. Emergent (N1), young (N2), mature (N3), and old (N4) nodules were harvested in liquid nitrogen at 5 to 7,13 to 15,34 to 40 , and 50 to 56 days post inoculation, respectively. Control roots from unnodulated plants were harvested at the same age as emergent nodules. Root and nodule material was stored at $-80^{\circ} \mathrm{C}$, except for nodules to be used for immunohistolocalization studies, which were processed fresh.

\section{Isolation and characterization of $L j S O D$ genes.}

The LjSOD genes were isolated by screening bacterial artificial chromosome and transformation-competent artificial chromosome genomic libraries (Sato et al. 2001) with genespecific primers based on their cDNA sequences. As a result, the genomic clones $L j C u Z n S O D c(\mathrm{LjB} 12 \mathrm{~K} 22)$, LjMnSOD

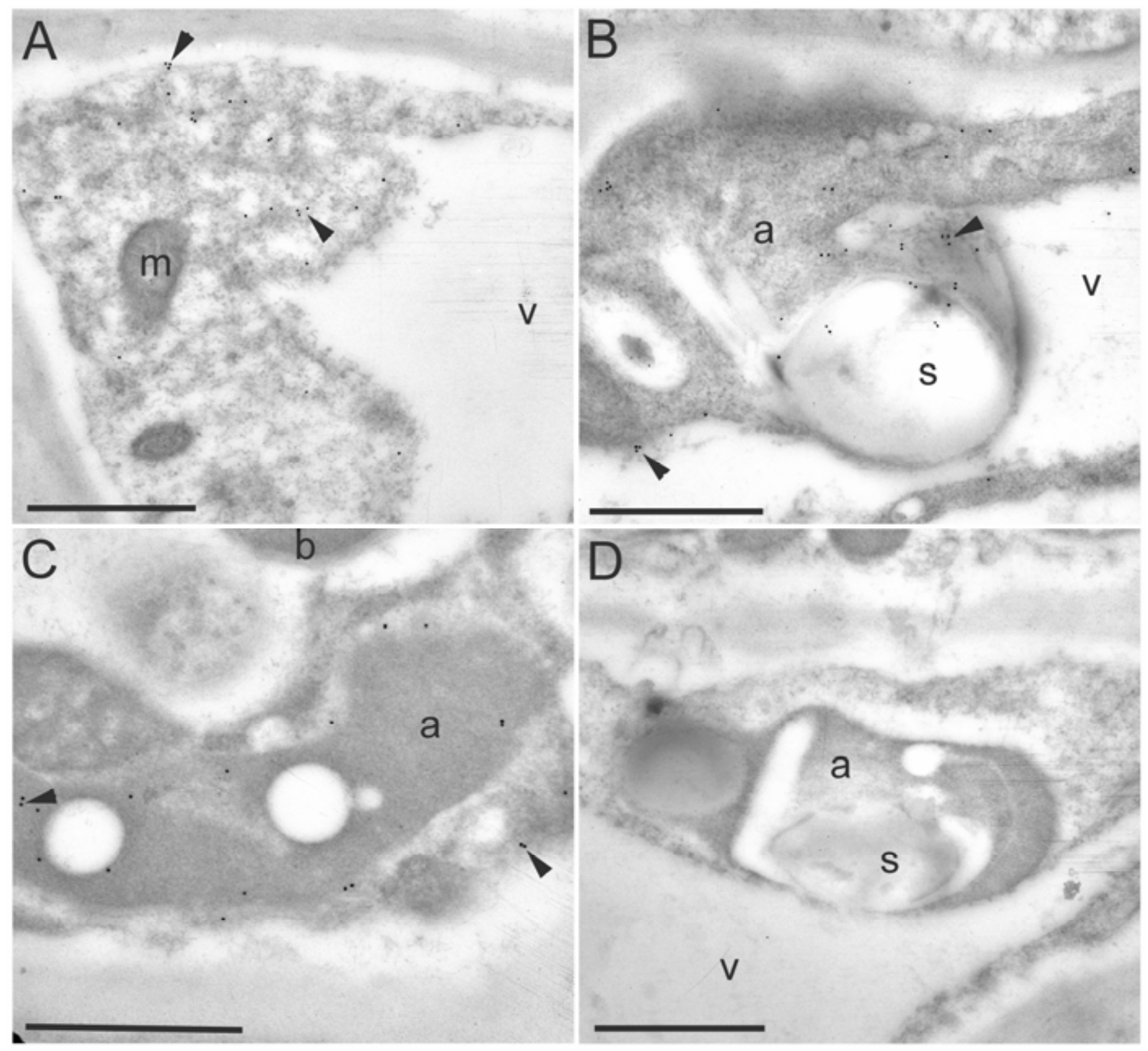

Fig. 9. Immunogold localization of LjFeSODs in nodules. Images represent transversal sections of mature (N3) nodules. A, Labeling (arrowheads) in the cytosol of an uninfected (interstitial) cell of the central zone. B, Labeling (arrowheads) in amyloplasts of an interstitial cell. C, Labeling (arrowheads) in the amyloplasts and cytosol of an infected cell. D, Control sections of an interstitial cell incubated with nonimmune serum. Abbreviations: a, amyloplast; b, bacteroid; m, mitochondrion; s, starch granule; $\mathrm{v}$, vacuole. Bars $=1 \mu \mathrm{m}$. 
(LjT13P21), LjFeSOD1 (LjT32I13), and LjFeSOD2 (LjT45M19) were isolated. The LjCuZnSODc (TC8588) and LjMnSOD (TC8244) cDNA sequences were available in the TIGR Lotus Gene Index database. To isolate the LjFeSOD clones, an L. japonicus nodule cDNA $\lambda$ ZAP library (kindly provided by J. Stougaard, Denmark) was PCR screened. The 5'- and 3'-end regions of the LjFeSOD1 cDNA were amplified using primers based on the single EST available (BP034738). Specifically, the $5^{\prime}$-end region was amplified with the primers 5'-CTCTCTCTCCTTCTCTGCAA-3' and T3 (5'-AATTAACC CTCACTAAAGGG-3'), and the $3^{\prime}$-end region with the primers 5'-GGAGAAGAACAGAGGAAGAAGA-3' and T7 (5'-GC GTAATACGACTCACTATAGGGC-3'). An internal fragment of the LjFeSOD2 cDNA sequence was obtained by PCR screening the nodule cDNA library using degenerated primers (5'-GC[A/T]TTCAACAA[T/C]GC[T/A]GC[T/A]CAGG-3' and 5'-TC[A/C]AG[G/A]TAGTAAGCATGCTCCCA-3'), based on conserved sequences of the FeSODs (GenBank accession numbers in parentheses) from Chlamydomonas reinhardtii (U22416), N. plumbaginifolia (M55909), A. thaliana (P21276), and G. $\max (\mathrm{M} 64267)$. The $5^{\prime}$ - and $3^{\prime}$-end regions of the LjFeSOD2 cDNA then were amplified using, for the $5^{\prime}$ end, the primers 5'-ATGTCAGCACTGGCAAGGAA-3' and T3 and, for the $3^{\prime}$ end, the primers $5^{\prime}$-TGGTTATTACCCACTCA TGA- $3^{\prime}$ and T7.

The PCR mix contained $240 \mathrm{nM}$ primers, $240 \mu \mathrm{M}$ deoxynucleoside triphosphates, and 0.5 to $1 \mathrm{U}$ of SuperTaq DNA polymerase (BV Sphaero Q, Gorinchem, The Netherlands) in a final volume of $25 \mu \mathrm{l}$ of PCR buffer. To amplify an internal fragment of $\mathrm{LjFeSOD2}$, the PCR program comprised an initial denaturation step of $2.2 \mathrm{~min}$ at $95^{\circ} \mathrm{C}, 40$ cycles of amplification $\left(45 \mathrm{~s}\right.$ at $95^{\circ} \mathrm{C}, 45 \mathrm{~s}$ at $62^{\circ} \mathrm{C}$, and $60 \mathrm{~s}$ at $72^{\circ} \mathrm{C}$ ), and a final elongation step of $10 \mathrm{~min}$ at $72^{\circ} \mathrm{C}$. To amplify the $5^{\prime}-$ and $3^{\prime}$-end fragments of $L j F e S O D 1$ and LjFeSOD2, the PCR consisted of two steps. The first PCR program for LjFeSODI comprised $4 \mathrm{~min}$ at $94^{\circ} \mathrm{C}$, followed by 40 cycles of amplification (for the $5^{\prime}$-end fragment, $45 \mathrm{~s}$ at $94^{\circ} \mathrm{C}, 60 \mathrm{~s}$ at $54.9^{\circ} \mathrm{C}$, and $60 \mathrm{~s}$ at $72^{\circ} \mathrm{C}$; or, for the $3^{\prime}$-end fragment, $60 \mathrm{~s}$ at $94^{\circ} \mathrm{C}, 60$ $\mathrm{s}$ at $53.5^{\circ} \mathrm{C}$, and $60 \mathrm{~s}$ at $72^{\circ} \mathrm{C}$ ), and $10 \mathrm{~min}$ at $72^{\circ} \mathrm{C}$. The first PCR program for $\mathrm{LjFeSOD} 2$ comprised $4 \mathrm{~min}$ at $94^{\circ} \mathrm{C}$, followed by 40 cycles of amplification (for the $5^{\prime}$-end fragment, $45 \mathrm{~s}$ at $94^{\circ} \mathrm{C}, 60 \mathrm{~s}$ at $56^{\circ} \mathrm{C}$, and $60 \mathrm{~s}$ at $72^{\circ} \mathrm{C}$; or, for the $3^{\prime}$-end fragment, $45 \mathrm{~s}$ at $94^{\circ} \mathrm{C}, 45 \mathrm{~s}$ at $53.5^{\circ} \mathrm{C}$, and $60 \mathrm{~s}$ at $72^{\circ} \mathrm{C}$ ), and $10 \mathrm{~min}$ at $72^{\circ} \mathrm{C}$. In both cases, the second PCR was run with the same primers and PCR conditions described above, but using as template $5 \mu$ of the product obtained in the first PCR. The PCR products were gel purified with the Qiaquick gel extraction kit protocol (Qiagen, Hilden, Germany), cloned in the pCR4-TOPO vector using the TOPO TA cloning kit (Invitrogen, Carlsbad, CA, U.S.A.), and sequenced on both strands.

The predicted LjFeSOD amino acid sequences, along with other sequences from green algae and higher plants, were used to construct a phylogenetic tree by the neighbor-joining method with CLUSTALW1.75 (Thompson et al. 1994) and TreeView (Page 1996) programs. Subcellular localization predictions and signal peptide analyses were performed using the programs MitoProtII (Claros and Vincens 1996), PSORT (Nakai and Kanehisa 1991), and ChloroP and TransitP (Center for Biological Sequence Analysis, Department of Biotechnology, Technical University of Denmark).

\section{Real-time qRT-PCR.}

Total RNA was isolated from roots and nodules using the RNAqueous kit (Ambion, Cambridgeshire, U.K.). The RNA was treated with DNaseI (Roche, Penzberg, Germany) at $37^{\circ} \mathrm{C}$ for $30 \mathrm{~min}$ and the absence of contamination with genomic DNA was tested in RNA samples using the primers of the plant (LjUbiquitin) and bacterial (MlsigA) housekeeping genes (Table 2 ). Reverse transcription was performed using poly- $\mathrm{T}_{17}$ primer and Moloney murine leukemia virus reverse transcriptase (Promega Corp., Madison, WI, U.S.A.).

Real-time qRT-PCR was carried out in the iCycler iQ System (Bio-Rad, Hercules, CA, U.S.A.) using the iQ SYBR-Green Supermix (Bio-Rad) and gene-specific primers (Table 2). The PCR program consisted of an initial denaturation and Taq activation step of $5 \mathrm{~min}$ at $95^{\circ} \mathrm{C}$, followed by 50 cycles of $15 \mathrm{~s}$ at $95^{\circ} \mathrm{C}$ and $1 \mathrm{~min}$ at $60^{\circ} \mathrm{C}$. A melting curve analysis was performed after every PCR reaction to confirm the accuracy of each amplified product. All reactions were set up in duplicate. The mRNA levels were normalized against the housekeeping genes and were expressed relative to the values of the emergent nodules (N1), using the $2^{-\Delta \Delta C t}$ method (Livak and Schmittgen 2001).

\section{Immunoblot analysis.}

Proteins were extracted from roots, nodules, and leaves at $4^{\circ} \mathrm{C}$ with $50 \mathrm{mM}$ potassium phosphate buffer ( $\mathrm{pH} 7.8$ ) containing $0.1 \mathrm{mM}$ EDTA, $1 \%$ (wt/vol) polyvinylpyrrolidone-10, and $0.1 \%$ (vol/vol) Triton X-100, and were quantified by the Bradford microassay (Bio-Rad). Free-living bacteria were grown at $28^{\circ} \mathrm{C}$ in yeast extract-mannitol medium, were harvested by centrifugation, and were disrupted by sonication (Becana et al. 1989). Bacteroids were purified from nodules by differential centrifugation and were broken by sonication (Becana et al. 1989). Proteins were resolved in $12.5 \%$ SDSPAGE gels and $15 \%$ native-PAGE gels, and were transferred onto polyvinylidene fluoride membranes using a transfer buffer consisting of $25 \mathrm{mM}$ Tris- $\mathrm{HCl}$ (pH 8.3), $192 \mathrm{mM}$ glycine, and $20 \%$ methanol (SDS-PAGE) or $0.7 \%$ acetic acid (native-PAGE). Equal loading of lanes and transfer quality were verified by Ponceau staining of membranes. Immunoblot analysis was performed using rabbit polyclonal antibodies raised against CuZnSODc of Spinacea oleracea (Kanematsu and Asada 1990), MnSOD of O. sativa (Kanazawa et al. 2000), and V. unguiculata FeSOD (Moran et al. 2003) at dilutions of 1:3,000, 1:5,000, and 1:1,000, respectively. Goat anti-rabbit IgG horseradish peroxidase conjugated (Sigma,

Table 2. Gene-specific primers used for real-time quantitative reverse-transcription polymerase chain reaction

\begin{tabular}{|c|c|c|c|}
\hline Genes & Accession number & Forward primers & Reverse primers \\
\hline LjUbiquitin & TC14061 & 5'-TTCACCTTGTGCTCCGTCTTC-3' & 5'-AACAACAGCACACACAGACAA-3' \\
\hline$L j A P X C$ & TC7951 & 5'-AAGGCCAGGAGAAAGCTCAGA-3' & 5'-AGCAGAGTGCCATGCCAAA-3' \\
\hline LjNin & AJ239041 & 5'-AATGCTCTTGATCAGGCTG-3' & 5'-AGGAGCCCAAGTGAGTGCTA-3' \\
\hline $\mathrm{LjCuZnSODc}$ & AY257198 & 5'-TGAACAATGGTGAAGGCTGTG-3' & 5'-CCTTGACATTATCGCTGCTGC-3' \\
\hline LjMnSOD & AY274807 & 5'-CCTCAGCCGTCGTTAAGCTC-3' & 5'-GACCTCCGCCATTGAATTTG-3' \\
\hline LjFeSOD1 & AY525602 & 5'-TCGCCATCCACTTCCACTACT-3' & 5'-GAAACGCGGAAGGTGATGAT-3' \\
\hline LjFeSOD2 & AY525604 & 5'-GGTTGCAAAATCTCAGCTTGC-3' & 5'-GCTGGAGTGACTTTTGGACCC-3' \\
\hline MlsigA & mll2466 & $5^{\prime}$-GCCCTCTGCTCGACCTTTCC-3' & 5'-AGCATCGCCATCGTGTCCTC-3' \\
\hline MlnifH & mlr5905 & 5'-GGCGTCATCACCTCGATCA-3' & 5'-ATTGTCATAGGCGCCGTTCT-3' \\
\hline$M I M n S O D$ & $\mathrm{mlr} 7636$ & 5'-TCGGTCGAAGAGGTGGTCA -3' & 5'-GAAGAGACCGGCATTCTTGC -3' \\
\hline
\end{tabular}


St. Louis) was used as secondary antibody at a dilution of 1:20,000. Immunoreactive proteins were visualized using a highly sensitive chemiluminescent reagent for peroxidase detection (SuperSignal West Pico, Pierce, Rockford, IL, U.S.A.).

\section{Immunohistolocalization of SODs in L. japonicus nodules.}

Fresh tissue was fixed in 4\% paraformaldehyde diluted in $1 \times$ phosphate-buffered saline (PBS) buffer with $10 \mathrm{mM}$ dithiothreitol (DTT), incubated overnight at $4^{\circ} \mathrm{C}$, dehydrated in an ethanol series containing $10 \mathrm{mM}$ DTT at room temperature, and embedded in butyl/methyl methacrylate containing $10 \mathrm{mM}$ DTT and $0.5 \%$ (wt/vol) benzoin ethyl ether for UV polymerization at $-20^{\circ} \mathrm{C}$ for 2 days according to Ruzin (1999). Sections of $5 \mu \mathrm{m}$ were made with a Leica RM 2165 rotary microtome and floated on drops of water on BIOBOND coated slides (Electron Microscopy Sciences, Hatfield, PA, U.S.A.). Slides were dried on a hot plate and butyl/methyl methacrylate was removed from the sections by acetone treatment. The immunohistolocalization was performed essentially as described (Grønlund et al. 2005). Sections were washed in $1 \times$ PBS and proteins were denatured in $12 \mathrm{mM}$ Tris- $\mathrm{HCl}$ ( $\mathrm{pH}$ 6.8) buffer containing $0.4 \%$ SDS and $3 \mathrm{mM} \beta$-mercaptoethanol. Then, blocking was done by incubating the slides for $15 \mathrm{~min}$ in 20 $\mathrm{mM}$ Tris- $\mathrm{HCl}(\mathrm{pH} 8.2)$ containing $0.9 \% \mathrm{NaCl}, 0.01 \% \mathrm{BSA}_{\mathrm{c}}$ (Aurion, Wageningen, The Netherlands), and $0.02 \%$ fish skin gelatin (Sigma).

The same rabbit polyclonal antibodies described above were used as primary antibodies for the immunohistolocalization studies. Primary antibodies were diluted 1:1,500 (CuZnSODc), 1:5,000 (MnSOD), or 1:125 (FeSOD) in the blocking solution containing $0.1 \% \mathrm{BSA}_{-\mathrm{c}}$. The secondary antibody was goat Alexa488-conjugated anti-rabbit immunoglobulin G (Molecular Probes, Eugene, OR, U.S.A.) at a 1:250 dilution in the same buffer. Slides were rinsed and mounted in gelvatol $(16.6 \%$ [wt/vol] polyvinyl alcohol and 33.3\% [vol/vol] glycerol in 1× PBS) containing 0.89 M DABCO (Acros Organics, Geel, Belgium) as antifading agent. Detection was performed by monitoring the signal by confocal laser-scanning microscopy, using an upright Zeiss microscope coupled to a Bio-Rad 1024 scan head and a Zeiss Axioplan 2 imaging microscope equipped with epifluorescence and differential interference contrast optics. No signal was observed using the first antibody alone, the secondary antibody alone, or buffer as controls.

\section{Immunogold localization of FeSODs in L. japonicus nodules.}

Mature nodules (N3) were high-pressure frozen, freeze-substituted, and embedded in low-temperature resin as described (Moran et al. 2003). Ultrathin sections were immunogold labeled with the same antibody as above, but the antibody was used at a concentration of 1:10. Serial sections treated with nonimmune serum (diluted 1:10) were used as a negative control.

\section{Activity and isozyme composition of SODs.}

SODs were extracted from roots or nodules as described for immunoblots, and total SOD activities were measured spectrophotometrically at $25^{\circ} \mathrm{C}$ by the ferric cytochrome $c$ method (Rubio et al. 2001). The SOD isoforms were individualized by $15 \%$ native-PAGE and subsequent staining of gels by the nitroblue tetrazolium method (Rubio et al. 2001). Isoforms were identified on gels by inhibition with $3 \mathrm{mM} \mathrm{KCN}$ or $5 \mathrm{mM}$ $\mathrm{H}_{2} \mathrm{O}_{2}$. Specific activities of the SOD isoforms were determined by taking into account the relative proportions determined by densitometry (ImageJ software; National Institutes of Health, Bethesda, MD, U.S.A.) and the total SOD activities.

\section{ACKNOWLEDGMENTS}

This work was supported by grants MERG-7-CT-2005-517605 and FP6-2003-INCO-DEV2-517617 from the European Commission and AGL2005-01404 from the Ministerio de Educación y Ciencia and Fondo Europeo de Desarrollo Regional. M. C. Rubio was the recipient of a Marie Curie Individual Fellowship of the European Commission (HPMF-CT2002-0943) and a postdoctoral contract (I3P program) of CSIC-FSE. We thank S. Kanematsu and T. Ushimaru for their generous gifts of the CuZnSODc and MnSOD antibodies, respectively, and G. E. M. Lamers for help with confocal and fluorescence microscopy.

\section{LITERATURE CITED}

Barón Ayala, M., and Sandmann, G. 1988. Activities of Cu-containing proteins in Cu-depleted pea leaves. Physiol. Plant. 72:801-806.

Becana, M., and Klucas, R. V. 1992. Transition metals in legume root nodules: Iron-dependent free radical production increases during nodule senescence. Proc. Natl. Acad. Sci. U.S.A. 89:8958-8962.

Becana, M., Paris, F. J., Sandalio, L. M., and del Río, L. A. 1989. Isoenzymes of superoxide dismutase in nodules of Phaseolus vulgaris L., Pisum sativum L., and Vigna unguiculata (L.) Walp. Plant Physiol. 90:1286-1292.

Bergersen, F. J. 1982. Root Nodules of Legumes: Structure and Functions. Wiley and Sons, Chichester, U.K.

Bridges, S. M., and Salin, M. L. 1981. Distribution of iron-containing superoxide dismutase in vascular plants. Plant Physiol. 68:275-278.

Claros, M. G., and Vincens, P. 1996. Computational method to predict mitochondrially imported proteins and their targeting sequences. Eur. J. Biochem. 241:779-786.

Dalton, D. A. 1995. Antioxidant defenses of plants and fungi. Pages 298355 in: Oxidative Stress and Antioxidant Defenses in Biology. S. Ahmad, ed. Chapman and Hall, New York.

Dalton, D. A., Hanus, F. J., Russell, S. A., and Evans, H. J. 1987. Purification, properties, and distribution of ascorbate peroxidase in legume root nodules. Plant Physiol. 83:789-794.

del Río, L. A., Sandalio, L. M., Altomare, D. A., and Zilinskas, B. A. 2003. Mitochondrial and peroxisomal manganese superoxide dismutase: Differential expression during leaf senescence. J. Exp. Bot. 54:923-933.

Droillard, M. J., and Paulin, A. 1990. Isozymes of superoxide dismutase in mitochondria and peroxisomes isolated from petals of carnation (Dianthus caryophyllus) during senescence. Plant Physiol. 94:1187-1192.

Evans, P. J., Gallesi, D., Mathieu, C., Hernandez, M. J., de Felipe, M. R., Halliwell, B., and Puppo, A. 1999. Oxidative stress occurs during soybean nodule senescence. Planta 208:73-79.

Farrer, T., Roller, B., Kent, W. J., and Zahler, A. M. 2002. Analysis of the role of Caenorhabditis elegans GC-AG introns in regulated splicing. Nucleic Acids Res. 30:3360-3367.

Fink, R. C., and Scandalios, J. G. 2002. Molecular evolution and structurefunction relationships of the superoxide dismutase gene families in angiosperms and their relationship to other eukaryotic and prokaryotic superoxide dismutases. Arch. Biochem. Biophys. 399:19-36.

Grønlund, M., Agalou, A., Rubio, M. C., Lamers, G. E. M., Roussis, A., and Spaink, H. P. 2005. Embedding of Lotus japonicus root and nodule tissue in plastic (BMM): Its use in immunocytochemistry and in situ RNA::RNA hybridisation studies. Pages 111-122 in: Lotus japonicus Handbook. A. J. Márquez, ed. Springer, Dordrecht, The Netherlands.

Hernández-Jiménez, M. J., Lucas, M. M., and de Felipe, M. R. 2002. Antioxidant defence and damage in senescing lupin nodules. Plant Physiol. Biochem. 40:645-657.

Kaminaka, H., Morita, S., Tokumoto, M., Yokoyama, H., Masumura, T., and Tanaka, K. 1999. Molecular cloning and characterization of a cDNA for an iron-superoxide dismutase in rice (Oryza sativa L.). Biosci. Biotechnol. Biochem. 63:302-308.

Kanazawa, S., Sano, S., Koshiba, T., and Ushimaru, T. 2000. Changes in antioxidative enzymes in cucumber cotyledons during natural senescence: Comparison with those during dark-induced senescence. Physiol. Plant. 109:211-216.

Kanematsu, S., and Asada, K. 1990. Characteristic amino acid sequences of chloroplast and cytosol isozymes of CuZn-superoxide dismutase in spinach, rice and horsetail. Plant Cell Physiol. 31:99-112.

Kliebenstein, D. J., Monde, R. A., and Last, R. L. 1998. Superoxide dismutase in Arabidopsis: An eclectic enzyme family with disparate regulation and protein localization. Plant Physiol. 118:637-650.

Kurepa, J., Bueno, P., Kampfenkel, K., Van Montagu, M., Van den Bulcke, M., and Inzé, D. 1997a. Effects of iron deficiency on iron superoxide dismutase expression in Nicotiana tabacum. Plant Physiol. Biochem. $35: 467-474$. 
Kurepa, J., Hérouart, D., Van Montagu, M., and Inzé, D. 1997b. Differential expression of $\mathrm{CuZn}$ - and Fe-superoxide dismutase genes of tobacco during development, oxidative stress, and hormonal treatments. Plant Cell Physiol. 38:463-470.

Kurepa, J., Van Montagu, M., and Inzé, D. 1997c. Expression of sodCp and $\operatorname{sodB}$ genes in Nicotiana tabacum: Effects of light and copper excess. J. Exp. Bot. 48:2007-2014.

Livak, K. J., and Schmittgen, T. D. 2001. Analysis of relative gene expression data using real-time quantitative PCR and the $2^{-\Delta \Delta C t}$ method. Methods 25:402-408.

Matamoros, M. A., Dalton, D. A., Ramos, J., Clemente, M. R., Rubio, M. C., and Becana, M. 2003. Biochemistry and molecular biology of antioxidants in the rhizobia-legume symbiosis. Plant Physiol. 133:499-509.

Mittler, R., and Zilinskas, B. A. 1992. Molecular cloning and characterization of a gene encoding pea cytosolic ascorbate peroxidase. J. Biol. Chem. 267:21802-21807.

Mittler, R., Vanderauwera, S., Gollery, M., and Van Breusegem, F. 2004 Reactive oxygen gene network of plants. Trends Plant Sci. 9:490-498.

Moran, J. F., James, E. K., Rubio, M. C., Sarath, G., Klucas, R. V., and Becana, M. 2003. Functional characterization and expression of a cytosolic iron-superoxide dismutase from cowpea root nodules. Plant Physiol. 133:773-782.

Nakai, K., and Kanehisa, M. 1991. Expert system for predicting protein localization sites in gram-negative bacteria. Proteins 11:95-110.

Page, R. D. M. 1996. TREEVIEW: An application to display phylogenetic trees on personal computers. Comput. Appl. Biosci. 12:357-358.

Puppo, A., Dimitrijevic, L., and Rigaud, J. 1987. $\mathrm{O}_{2}$ consumption and superoxide dismutase content in purified mitochondria from soybean root nodules. Plant Sci. 50:3-11.

Rubio, M. C., Ramos, J., Webb, K. J., Minchin, F. R., Gonzalez, E., Arrese-Igor, C., and Becana, M. 2001. Expression studies of superoxide dismutases in nodules and leaves of transgenic alfalfa reveal abundance of iron-containing isozymes, posttranslational regulation, and compensation of isozyme activities. Mol. Plant-Microbe Interact. 14:11781188.

Rubio, M. C., James, E. K., Clemente, M. R., Bucciarelli, B., Fedorova M., Vance, C. P., and Becana, M. 2004. Localization of superoxide dismutases and hydrogen peroxide in legume root nodules. Mol. PlantMicrobe Interact. 17:1294-1305.
Ruzin, S. E. 1999. Butyl/methyl methacrylate embedding. Page 4 in: Plant Microtechnique and Microscopy. S. E. Ruzin, ed. Oxford University Press, New York.

Santos, R., Hérouart, D., Sigaud, S., Touati, D., and Puppo, A. 2001. Oxidative burst in alfalfa-Sinorhizobium meliloti symbiotic interaction. Mol. Plant-Microbe Interact. 14:86-89.

Sato, S., Kaneko, T., Nakamura, Y., Asamizu, E., Kato, T., and Tabata, S. 2001. Structural analysis of a Lotus japonicus genome. I. Sequence features and mapping of fifty-six TAC clones which cover the $5.4 \mathrm{mb}$ regions of the genome. DNA Res. 31:311-318.

Scandalios, J. G. 1997. Molecular genetics of superoxide dismutases in plants. Pages 527-568 in: Oxidative Stress and the Molecular Biology of Antioxidant Defenses. Cold Spring Harbor Laboratory Press, Cold Spring Harbor, NY, U.S.A.

Schauser, L., Roussis, A., Stiller, J., and Stougaard, J. 1999. A plant regulator controlling development of symbiotic root nodules. Nature 402:191-195.

Shapiro, M. B., and Senapathy, P. 1987. RNA splice junctions of different classes of eukaryotes: Sequence statistics and functional implications in gene expression. Nucleic Acids Res. 15:7155-7174.

Srivally, B., and Khanna-Chopra, R. 2001. Induction of new isoforms of superoxide dismutase and catalase enzymes in the flag leaf of wheat during monocarpic senescence. Biochem. Biophys. Res. Commun. 288:1037-1042.

Sparks, M. E., and Brendel, V. 2005. Incorporation of splice site probability models for non-canonical introns improves gene structure prediction in plants. Bioinformatics 21(Suppl. 3):iii20-iii30.

Thompson, J. D., Higgins, D. G., and Gibson, T. J. 1994. CLUSTAL W: Improving the sensitivity of progressive multiple sequence alignment through sequence weighting, positions-specific gap penalties and weight matrix choice. Nucleic Acids Res. 22:4673-4680.

Tsang, E. W. T., Bowler, C., Hérouart, D., Van Camp, W., Villarroel, R., Genetello, C., Van Montagu, M., and Inzé, D. 1991. Differential regulation of superoxide dismutases in plants exposed to environmental stress. Plant Cell 3:783-792.

Van Camp, W., Bowler, C., Villarroel, R., Tsang, E. W. T., Van Montagu, M., and Inzé, D. 1990. Characterization of iron superoxide dismutase cDNAs from plants obtained by genetic complementation in Escherichia coli. Proc. Natl. Acad. Sci. U.S.A. 87:9903-9907. 